\title{
Dynamic response of a reinforced concrete minaret
}

\author{
M. Günaydın*1, Z. Tonyalı ${ }^{2}$ \\ ${ }^{1}$ Gümüşhane University, Department of Civil Engineering, Gümüşhane, Turkey \\ ${ }^{2}$ Recep Tayyip Erdoğan University, Civil Engineering Department, 53100, Rize, Turkey
}

\begin{abstract}
Minarets are one of the specific structure types used commonly in Islamic Countries. Many minarets were damaged or collapsed during catastrophic events like earthquake. During an earthquake to understand the minarets' behavior are so important since dynamic response of these structures depends on a detailed understanding of their structural characteristics, such as geometrical shape, supporting system, mode shapes, natural frequencies and modal damping ratio etc. This paper examines in detail a Turkish style reinforced concrete (RC) minaret, its finite element modeling, modal analysis and earthquake analysis. A reinforced concrete minaret which is generally built in Turkey is selected as an application. Three-dimensional (3D) model of the minaret and its modal analysis are performed to obtain analytical frequencies and mode shapes using ANSYS finite element program. The minaret's linear transient analysis is carried out using the 1992 Erzincan earthquake ground motion record to obtain the earthquake behavior of the minaret. At the end of the study, the calculated displacement responses and maximum-minimum principal stresses concentrations for the minaret are briefly discussed and illustrated.
\end{abstract}

\section{Keywords}

Dynamic analysis; Finite element method; Turkish style RC minaret.

Received: 10 April 2018; Accepted: 28 May 2018

ISSN: 2630-5763 (online) C 2018 Golden Light Publishing® All rights reserved.

\section{Introduction}

Minarets are usually tall and slender tower structures with distinguished architectural characteristics and are constructed mostly next to the mosques. They were built with the aim of calling people to come to pray. Minarets have very different heights ranging from 15 to $210 \mathrm{~m}$ and different designs, with one, two or three balconies. The tallest minaret in the world at $210 \mathrm{~m}$ pertains to Hassan II Mosque in Casablanca, Morocco [1]. In the past, minarets in Turkey were built using solid brick masonry or stone blocks. But, the new generation minarets are recently made of reinforced concrete.
The great piece of land of Turkey is located within an active earthquake zone; because of this, Turkey has been exposed to so many destructive earthquakes. During these earthquakes, it is seen that many minarets were usually collapsed or severely damaged and many people have lost their lives and goods under the debris of minarets. The last earthquakes such as Erzincan, Afyon (Dinar), Kocaeli and Van confirm this information. Van earthquake $\left(\mathrm{M}_{\mathrm{w}}=7.2\right)$ occurred in 2011 in Turkey has several damages and these are shown in Fig. 1. Unfortunately, there are no structural code requirements or guidelines for the design of reinforced concrete minarets, or minarets in general, in Turkey. As a result, these slender

\footnotetext{
* Corresponding author

E-mail: mgunaydin@gumushane.edu.tr
} 
structures have been built, for the most part, by experienced contractors and construction workers with no engineering knowledge. In most cases, each contractor constructs a typical minaret with the same structural and architectural features regardless of the local soil conditions or seismicity of the region [2]. Hence, the structural safety of minarets has become of increasing concern due to powerful lateral loading such as earthquake and wind. As a matter of fact, the dynamic behavior of the minarets is not adequately known. So, the dynamic behavior of the minarets must be determined, especially under dynamic loads such as earthquake and wind.

In the literature, some papers exist about dynamic behavior of the minarets. El-Attar et al. [3] carried out a study on the dynamic behavior of Mamluk style minarets damaged during the Dahshur-Egypt earthquake in 1992. The minaret was modeled using the finite element method and was analyzed to assess its dynamic characteristics and its response under different input ground motions. Higazy [4] studied about the seismic response of historical monuments of Islamic Cairo representing different periods, namely, Abbasid/Tulunid (827 to 904), Fatimid (969 to 1171), Ayyubid (1171 to 1250), Mamluk (1250 to 1517) and Ottoman Turk (1517 to 1848).

El-Attar et al. [5] investigated the conservation of a slender historical Mamluk style minaret by passive control techniques. The seismic vulnerability of a representative Mamluk-style minaret, namely Manjaq Al-Yusufi is investigated and some seismic protection techniques are proposed and evaluated. A realistic 3D finite element model of the minaret that reflects those properties was constructed using COSMOS software. Ambient vibration tests were then performed on the minaret and its modal parameters such as fundamental periods and mode shapes were obtained. The ambient vibration test results were then used to update the finite element model. Ertek [6] studied about structural modeling and earthquake analysis of Ottoman minarets. Dogangun et al. [7] examined about the investigation of dynamic response of masonry minaret structures. To investigate the dynamic behavior of historical unreinforced masonry minarets, three representative minarets with 20, 25 and $30 \mathrm{~m}$ height were modeled and analyzed using two ground motions recorded during the 1999 Kocaeli and Duzce, Turkey earthquakes. Pena et al. [8] describes the seismic assessment of the Qutb Minar in Delhi, India. Three models with different levels of complexity and simplification were developed. The use of these models allows one to overcome the complexity of the study of the seismic behavior of ancient masonry structures; by combining the results of the different models. It is possible to obtain a better and more comprehensive interpretation of the seismic behavior. Haciefendioglu and Birinci [9] studied the stochastic seismic response analysis of masonry minarets subjected to random underground blast and earthquake-induced ground motions by using a three-dimensional finite element model.

Altunisik [10] investigated the dynamic response of masonry minarets before/after FRP composite strengthening. Iskenderpasa historical masonry minaret dating back to XVI century with a height of $21 \mathrm{~m}$ located in Trabzon, Turkey was selected as an application. Firstly, 3-D finite element model of the minaret was constituted using ANSYS software. Then, an analytical model of the minaret was analyzed using the 1992 Erzincan earthquake record, which occurred near the area, to determine the dynamic behavior. After this, the cylindrical body of the minaret was strengthened with FRP composite using different configurations and dynamic analyses were performed. In the study, dynamic responses of the minaret before and after FRP composite strengthening, such as displacements and maximum-minimum principal stresses, were compared. Bayraktar et al. [11,12] studied about the historical masonry minaret, its finite element modeling, modal testing, finite element model calibration and seismic response. Modal analysis is performed on the developed 3D finite element model of the minaret to obtain the analytical frequencies and mode shapes. Portioli et al. [13] performed a seismic retrofitting of Mustafa Pasha Mosque in Skopje. Finite element analysis 
was carried out to assess the seismic behavior of the mosque and the efficiency of a carbon-fiberreinforced polymer-based strengthening technique. Gang et al. [14] studied about the seismic reliability of Guang Minaret in frequently occurred earthquake to see if it met the reliability criterion demand. Oliveira et al. [15] performed a series of in situ ambient vibration tests to old minarets of various sizes and compared results of frequencies with numerical modeling of the same structures.

Damages occurred on RC minarets are dependent on some factors such as detailing and properties of the structure and its components, soil properties, and the magnitude of the earthquake. Observations from recent earthquakes suggest that the damage in the minarets is usually concentrated in a few specific locations [21]. These damages occurred on RC minarets under seismic actions can be classified as follows; damages on spire, upper part of the minaret body, cylindrical body, transition segment and pulpit. Damage to spire, upper part of the minaret body, transition segment and balcony levels were encountered less frequently damage type [22].

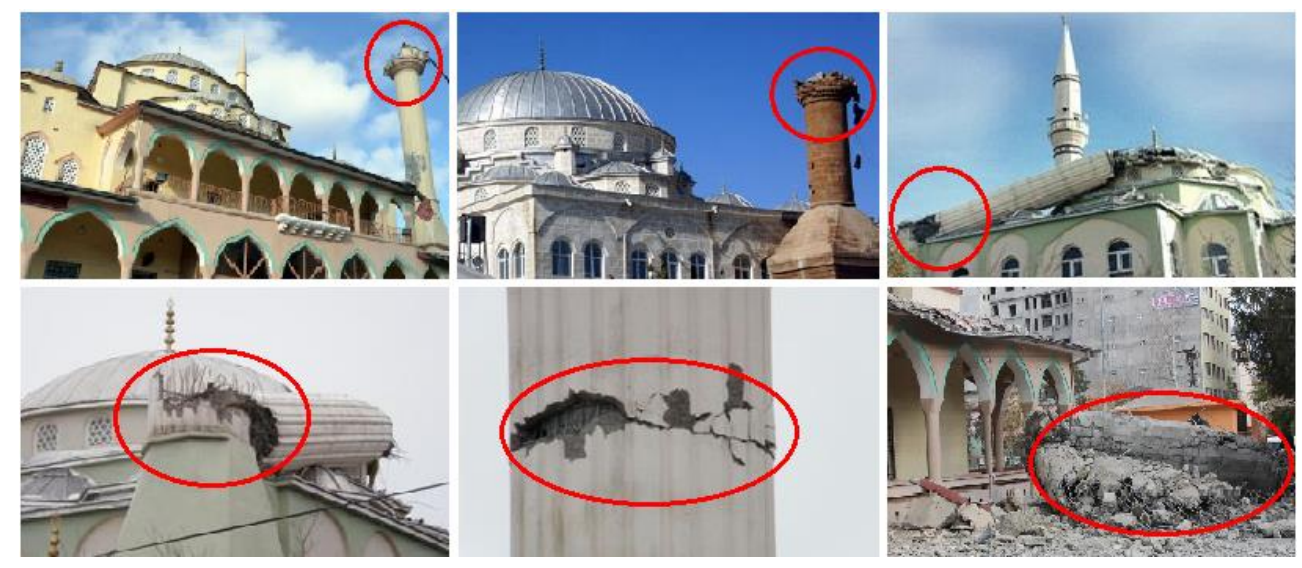

Fig. 1. Various damages of Van earthquake on the minarets in Turkey (URL-1)

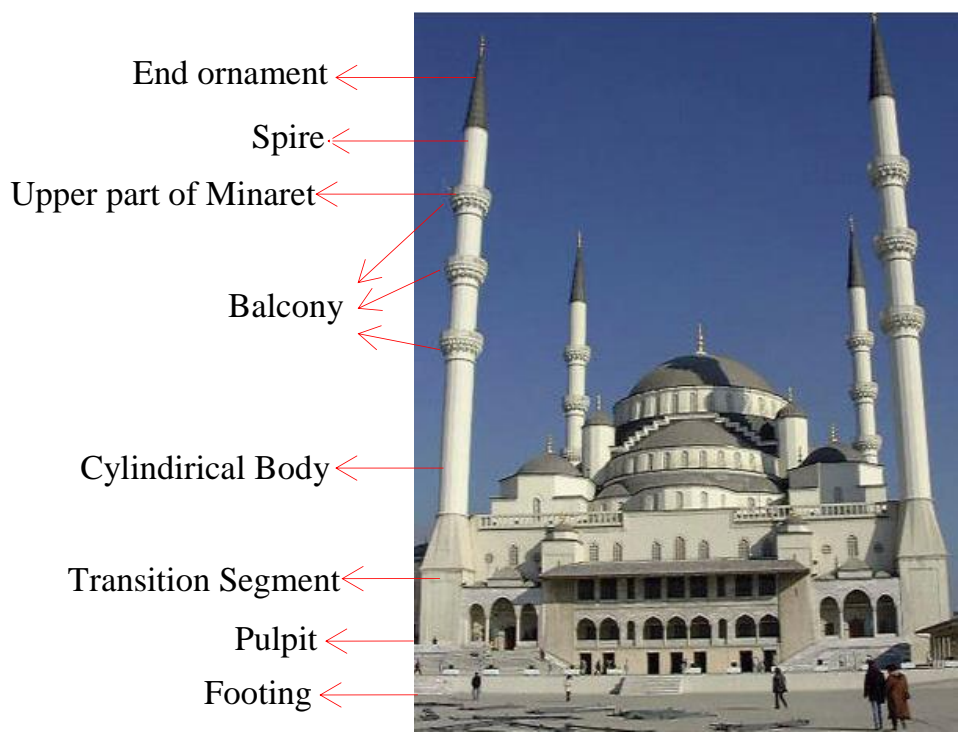

Fig. 2. Main parts of a Turkish style minaret (URL-2) 

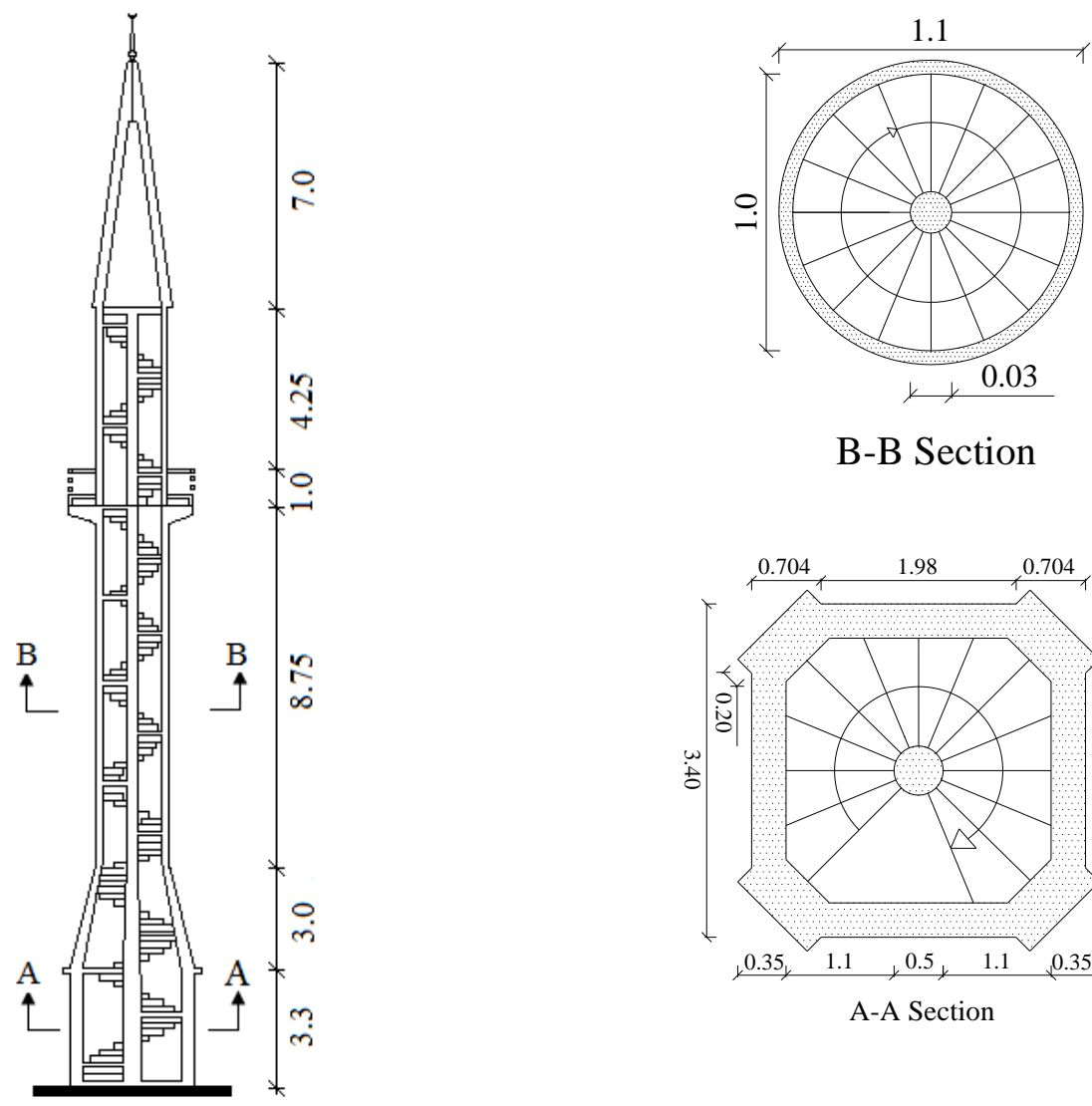

B-B Section

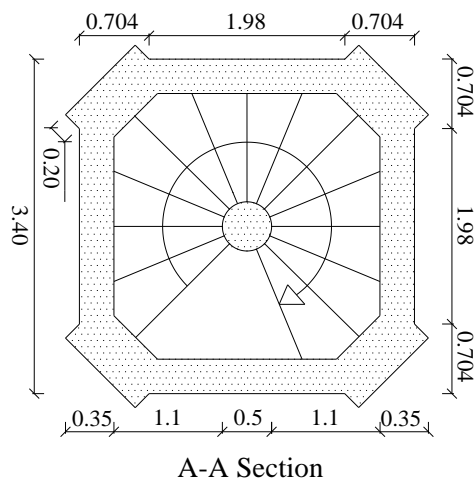

Fig. 3. Geometrical properties of minaret (dimensions as m)

Currently, there are so many constructed RC minarets in Turkey and the constructions of most of them are continuing still. However, there is no specific design code for the structural analysis of RC minarets which should be analyzed, designed and constructed in elaborative. Because of the lack of any code or standard, design and the construction of these tall and slender structures are mostly achieved by contractors or experienced worker which have no engineering knowledge, whereas, Turkey is a region that strong ground motions frequently occur [22].

As seen in literature, many articles can be found about to behavior of historical masonry minarets. However, there are only a few studies related to behavior of RC minarets [1,2,16-18]. To this end, studies on behavior of RC minarets are meagre and need to be enlarged by inserting new studies. In the light of aforementioned researches, assessment of dynamic performance of a reinforced concrete minaret is performed in this paper.

\section{Numerical application}

\subsection{Description of the Turkish style RC minaret}

Turkish style minarets are basically comprised of three parts such as base, shaft and gallery. The base is reached from soil to floor. The shaft is a thin body of the minaret and stairs are placed cylindrically in the shaft to provide the necessary structural support for highly elongated shafts. The gallery is a balcony which encircles the upper section where the muezzins call out to pray. It is covered by a rooflike canopy and adorned with ornaments such as decorative bricks and decorated with painted tiles, cornices and arches. In Turkish style, parts of minaret are; footing as a base; pulpit, transition segment, cylindrical or polygonal body as a shaft; 
balcony; upper part of a minaret body; spire; and flag as shown in Fig. 2.

\subsection{Description of the minaret}

A reinforced concrete minaret which is generally built in Turkey is selected as an application. Details of the minaret are shown in Figure 3. As can be seen in the Fig. 3, the minaret is slim and its total height is $28.30 \mathrm{~m}$ and has only one balcony on its body (shaft). In addition to these properties, there is a varying section concrete block along the minaret. Form the lower part of the pulpit to the upper part of the pulpit diameter of concrete block is $0.50 \mathrm{~m}$. In transition segment diameter of concrete block is varying. From the upper part of the transition segment to the lower part of the spire diameter of concrete block is $0.30 \mathrm{~m}$. There are 129 stairs from the floor to the upper part of minaret and they have $0.172 \mathrm{~m}$ step height. In the diameter of concrete block is $0.30 \mathrm{~m}$, each set of stairs has an inner and outer radius of $0.15 \mathrm{~m}$ and $0.80 \mathrm{~m}$, respectively.

\subsection{Finite element modeling}

The ANSYS finite element program is used to obtain analytical modal parameters. Mesh size is chosen as $0.20 \mathrm{~m}$. Therefore, in the finite element method (FEM) of the minaret, 44241 threedimensional (3D) SOLID186 elements, which exhibit quadratic displacement behavior are used. When the structural solid geometry property of the SOLID186 element is examined, it can be seen that the elements appear to be made of tetrahedral, pyramid or prism options in the finite element mesh model of the minaret. Each element has 20 nodes and each node has three degrees of freedom translations in the nodal $x, y$ and $z$ directions. The boundary conditions are defined by restraining all degrees of freedom under the bridge abutments, commonly known as fixed boundary conditions. In addition, it has the abilities of plasticity, hyper elasticity, creep, stress stiffening, large deflection and large strain capabilities [19]. The model which is used in this minaret system, FEM and body of the minaret and stairs are used as shown is Fig. 4.
Characterization of material properties and boundary conditions, which must be taken into consideration in the analytical analysis, is very important for thin and tall structures such as minarets. In this study, to obtain the dynamic characteristics of the minaret, the elasticity modulus, Poisson's ratio and mass per unit volume are given in Table 1 .

In the model, linear elastic material behavior is assumed. Rayleigh damping with five percent damping ratio is used in the linear dynamic analysis. The initial boundary conditions, all of the degrees of freedoms under the footing part of the minaret are fixed. such as natural frequencies, mode shapes and damping ratios of the engineering structures experimentally. In Figure 5, the first seven mode shapes and natural frequencies of the minaret obtained from analytical modal analysis are illustrated. Mode shapes are more or less similar in all modeled minarets. They are in pairs (orthogonal in the plane $\mathrm{x}-\mathrm{y}$ ) and torsion appears only in higher frequencies. As shown in Figure 5, the first six modes are bending modes and seventh mode is torsional mode.

Structural periods, natural frequencies and dynamic mass participation factors were estimated for the first seventh modes of the minarets and are given in Table 2 . The first period is approximately 0.8 seconds for the minaret. The frequencies of the first two modes are very close to each other due to partial symmetry feature of the structure. The mode shapes of the first and second modes which are given in Figure 5 also show a great resemblance as a result of the partial symmetry. The data in the table show that the contribution of the first mode to the dynamic response is $\% 42$ in $X$ direction and \% 6.6 in $Y$ direction. The higher modes affect the dynamic behavior of minaret structures.

Table 1. Material properties considered in analysis of the minaret

\begin{tabular}{ccc}
\hline$E\left(\mathrm{~N} / \mathrm{m}^{2}\right)$ & $v$ & $\rho\left(\mathrm{kg} / \mathrm{m}^{3}\right)$ \\
\hline $2.4 \mathrm{E} 10$ & 0.20 & 2169 \\
\hline
\end{tabular}



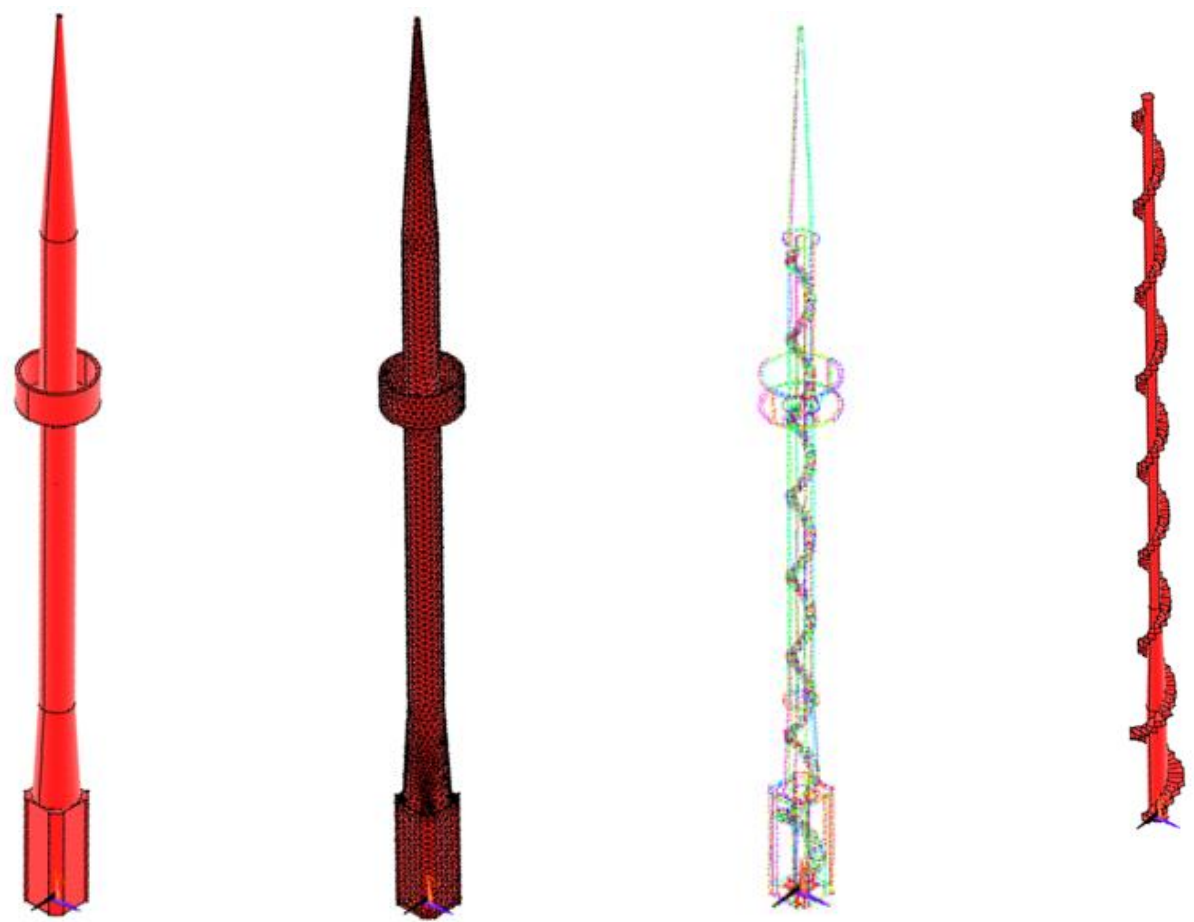

a) Minaret

b) Concrete block and stairs

Fig. 4. Three-dimensional FEM model of the minaret
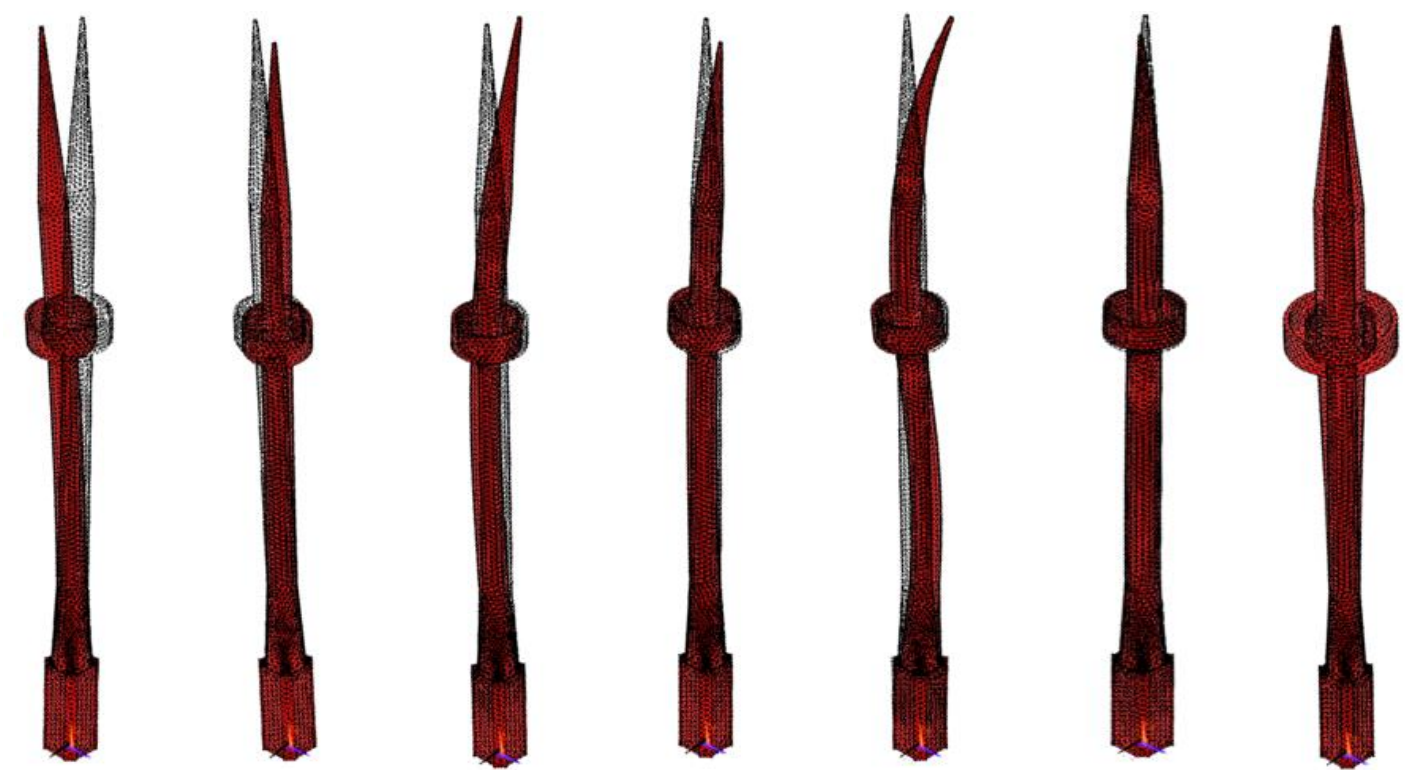

$f_{1}=1.126 \mathrm{~Hz}$ $f_{2}=1.127 \mathrm{~Hz}$

$f_{3}=6.013 \mathrm{~Hz}$

$f_{4}=6.019 \mathrm{~Hz}$

$f_{5}=14.55 \mathrm{~Hz}$

$f_{6}=14.57 \mathrm{~Hz}$

$f_{7}=17.12 \mathrm{~Hz}$

Fig. 5. The first seven modes and natural frequencies obtained from analytical analysis 
Table 2. Vibration modes, corresponding frequencies, periods and mass participation factors of the minaret

\begin{tabular}{cccccc}
\hline \multirow{2}{*}{ Modes } & Frequency & Period & \multicolumn{3}{c}{ Mass Participation Factors (\%) } \\
\cline { 2 - 6 } & $\mathrm{Hz}$ & $\mathrm{s}$ & $\mathrm{X}$ & $\mathrm{Y}$ & $\mathrm{Z}$ \\
\hline 1 & 1.1260 & 0.8881 & 40.2 & 6.6 & 0.0 \\
2 & 1.1269 & 0.8874 & 6.6 & 40.2 & 0.0 \\
3 & 6.0065 & 0.1665 & 10.7 & 3.5 & 0.0 \\
4 & 6.0127 & 0.1663 & 3.5 & 10.7 & 0.0 \\
5 & 14.5260 & 0.0689 & 4.2 & 4.9 & 0.0 \\
6 & 14.5320 & 0.0688 & 4.9 & 4.2 & 0.0 \\
7 & 17.1240 & 0.0584 & 0.0 & 0.0 & 16.8 \\
8 & 23.2380 & 0.0430 & 0.6 & 4.0 & 0.0 \\
9 & 23.2720 & 0.0429 & 4.0 & 0.6 & 0.0 \\
10 & 33.5620 & 0.0298 & 0.9 & 4.9 & 0.0 \\
\hline
\end{tabular}

\subsection{Linear earthquake behavior}

In this research, earthquake behavior of the minaret is investigated. Linear transient analysis of the minaret is carried out using ERZIKAN/ERZ-NS component of 1992 Erzincan ground motion (Fig. 6) [Url-3]. Element matrices are computed using the Gauss numerical integration technique [20]. The Newmark method is used in the solution of the equation of motion. Rayleigh damping constants were calculated between the first mode and the seventh mode of the minaret, assuming a 5\% damping ratio. Alpha and beta coefficients were calculated as 6.64 and 0.0088 , respectively. Because of needed too much memory for the analyses, the first 6.5 seconds of the ground motion, which is the most effective duration, are taken into account in calculations.

The horizontal displacement along to the height of the minaret at the time of maximum response is given in Figure 7. It is seen that the displacements increase along the height of the minaret and that the maximum displacement (at the top of the minaret) is obtained as $16 \mathrm{~cm}$. Besides, the time histories of the horizontal displacements (with a peak value of) $16 \mathrm{~cm}$ for analysis at the top of the minaret subjected to the Erzincan ground motion is presented in Figure 7.

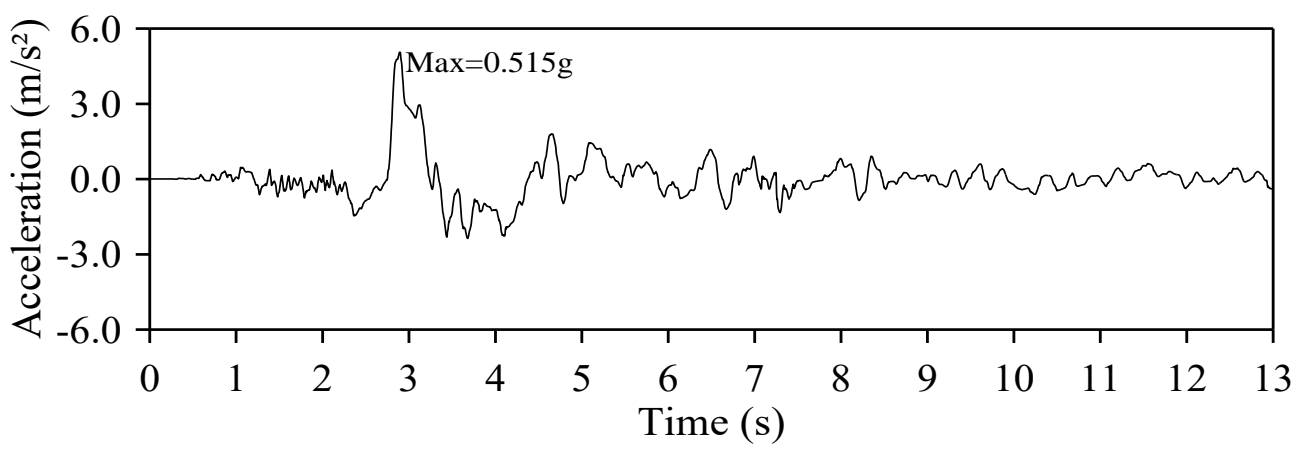

Fig. 6. Accelerogram of 1992 Erzincan earthquake 


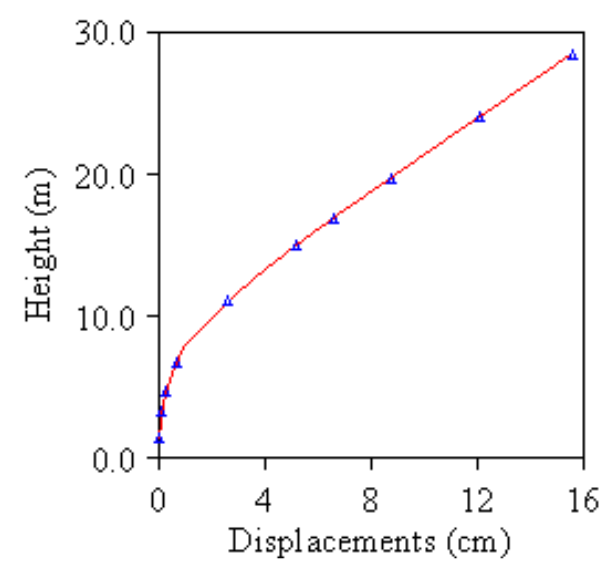

a)

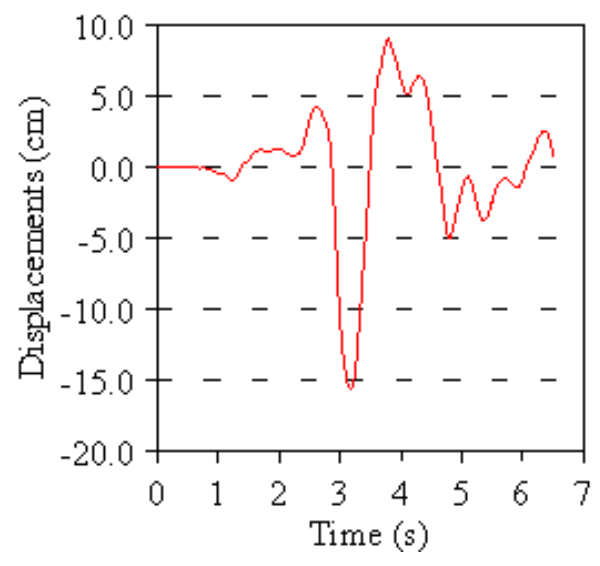

b)

Fig. 7. (a) Variation of maximum displacements along to the height of the minaret at the time of maximum response and (b) Time history of maximum displacement at the top of the minaret

The contour diagram of maximum horizontal displacement is shown in Fig. 8. This displacement contours represent the distribution of the peak values reached by the maximum displacement at each point within the section. It can be seen from this Figure, maximum displacement occurred at the top of the minaret. The time histories of the maximum and minimum principal stresses of the minaret exposed to the Erzincan Earthquake are plotted in Fig. 9.

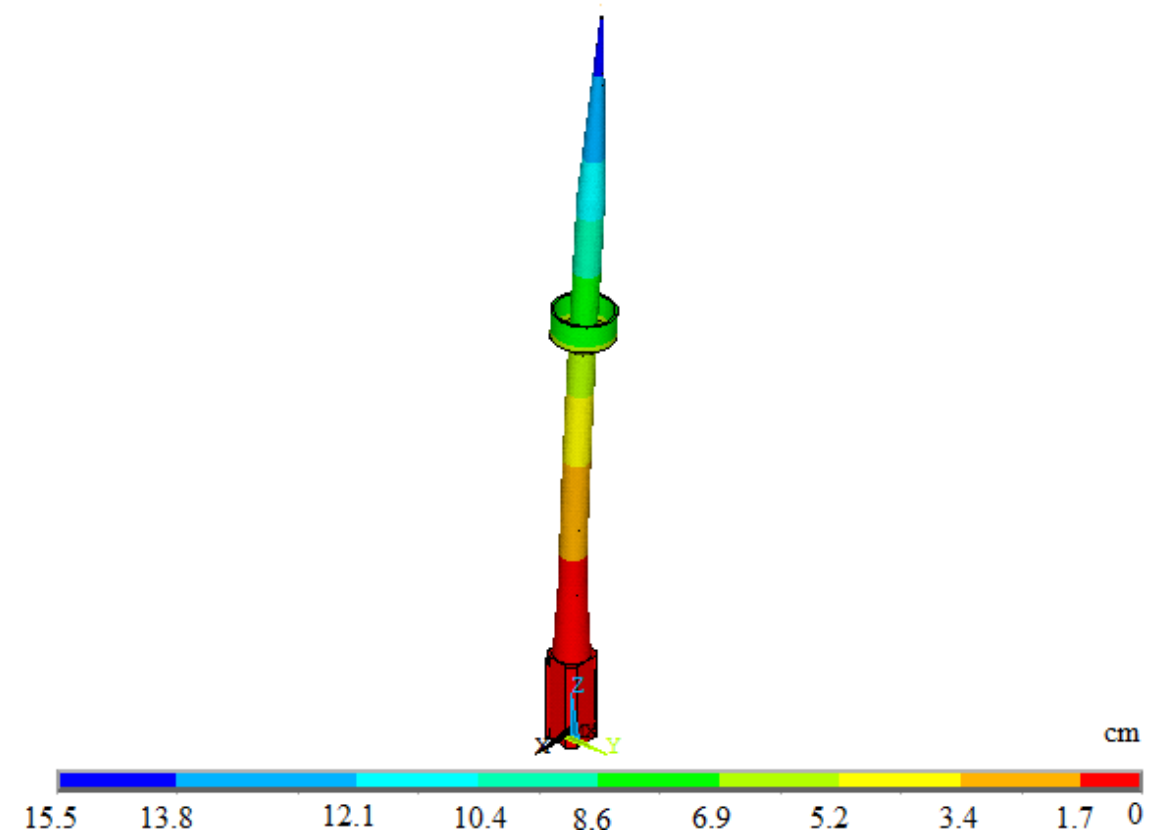

Fig. 8. Maximum displacement contour of the minaret 

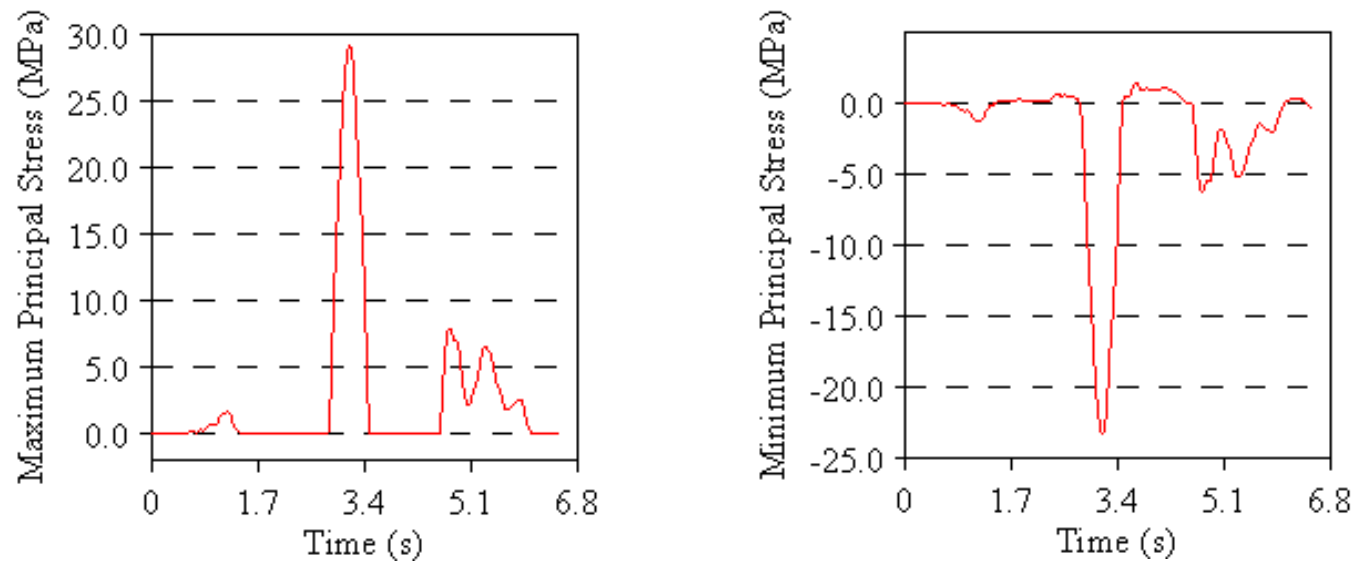

Fig. 9. The time histories of maximum and minimum principal stresses of the minaret

According to elasticity theory, when the normal vector of a surface and the stress vector acting on that surface are collinear, the direction of the normal vector is called principal stress direction. The magnitude of the stress vector on the surface is called the principal stress value. In this study, maximum and minimum principal stress contours of the minaret are plotted in Figures 10 and 11. These stress contours represent the distribution of the peak values reached by the maximum principal stress at each point within the section.

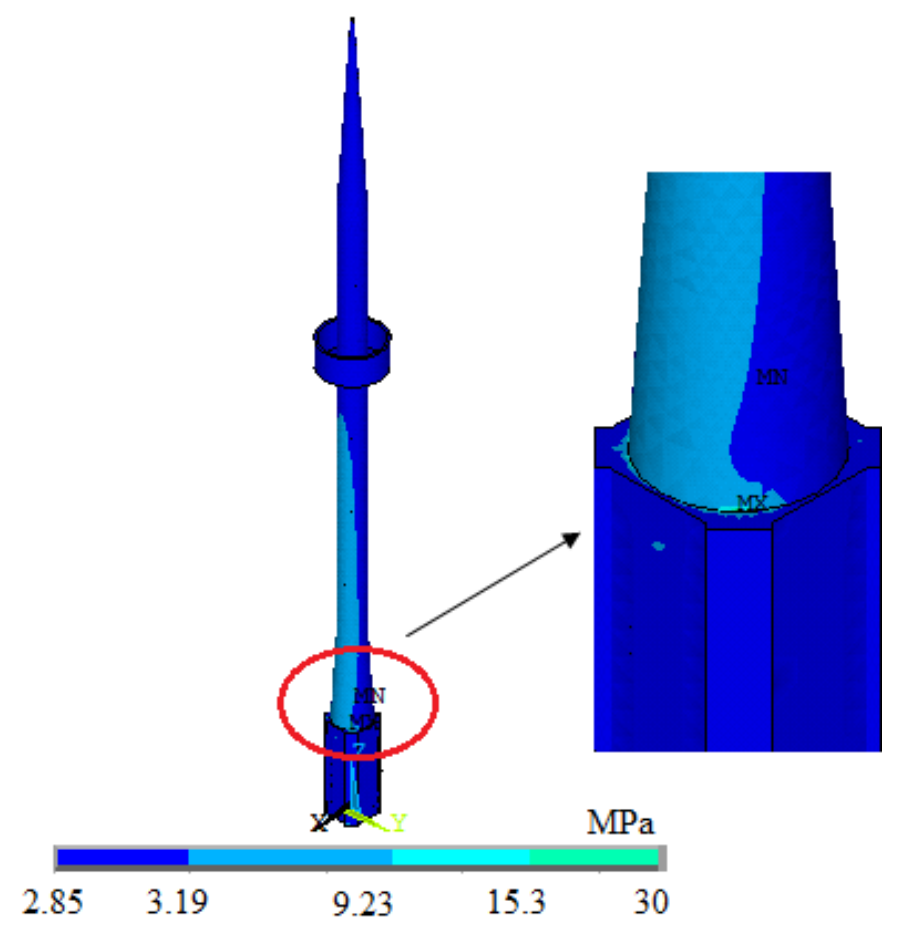

Fig. 10. Maximum principal stress contours of the minaret 


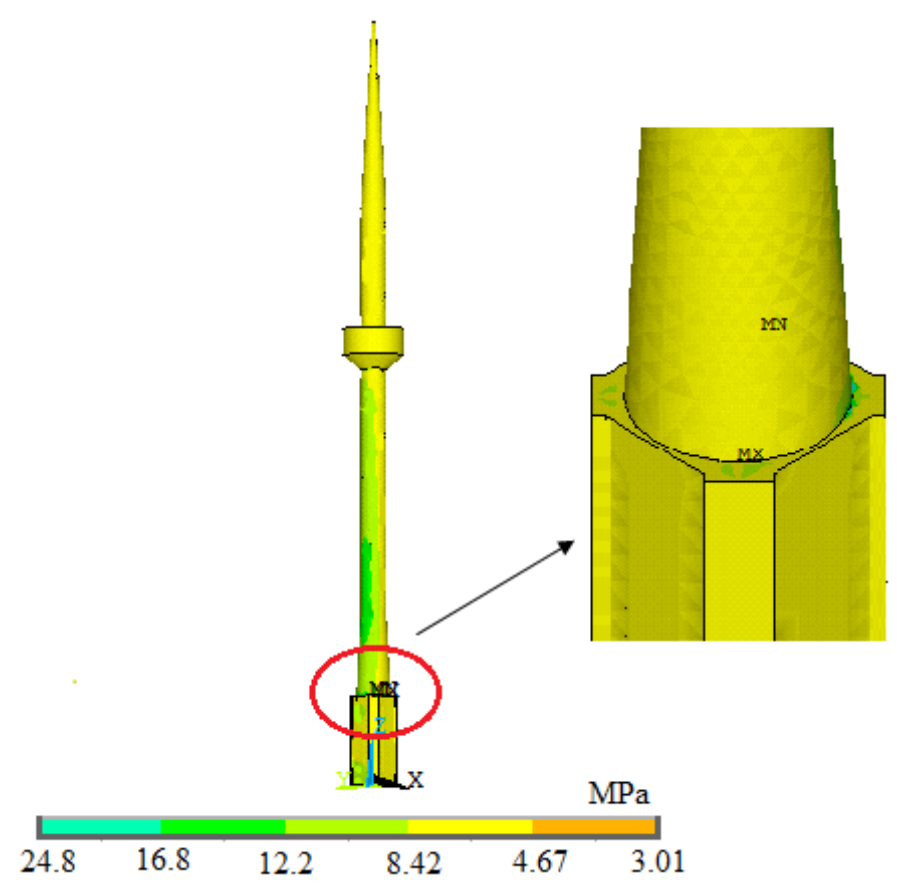

Fig. 11. Minimum principal stress contours of the minaret

\section{Conclusions}

This paper examines in detail a Turkish style reinforced concrete (RC) minaret, its finite element modeling, modal analysis and earthquake analysis. A Turkish style reinforced concrete minaret is selected as an application. The model minaret's total height is $28.30 \mathrm{~m}$ and has only one balcony. A 3-D finite element model of the minaret was performed using ANSYS software and its dynamic behavior was determined using 1992 Erzincan earthquake. In this study, the following observations can be obtained:

- A total of ten natural frequencies are obtained from the dynamic analysis of the minaret, which range between 1.13-33.56 $\mathrm{Hz}$. The first six modes are bending modes and the last mode is torsional mode.

- The horizontal displacements increase along to the height of the minaret and the maximum displacement occurs at the top of the minaret with a value of $16 \mathrm{~cm}$ at $3.27 \mathrm{~s}$.

- Maximum and minimum principal stress occurred at the region between the transitions segment and they are equal to
28.2 $\mathrm{MPa}$ and $24.8 \mathrm{MPa}$, respectively. Therefore, it is likely that damages and cracks during the earthquake loading can occur at transition region and minaret's cylindrically body.

\section{References}

[1] Winkler E. Theory of Elasticity and Strength. Dominicus Pague, 1867, Czechoslovakia.

[2] Bayraktar A, Sevim B, Altunışık AC, Türker T (2010) Earthquake analysis of reinforced concrete minarets using ambient vibration test results. The Structural Design of Tall and Special Buildings 19: 257-273.

[3] Sezen H, Acar R, Doğangün A, Livaoglu R (2008) Dynamic analysis and seismic performance of reinforced concrete minarets. Engineering Structures 30: 2253-2264.

[4] El-Attar AG, Saleh AM, Osman A. Seismic response of a historical Mamluk style minaret. Proceedings of the 3rd International Conference on Earthquake Resistant Engineering Structures, 2001, Malaga, Spain, 745-754.

[5] Higazy EM (2004) Vulnerability of historical minarets investigation of their seismic 
assessment \& retrofitting. Emirates Journal for Engineering Research 9: 59-64.

[6] El-Attar AG, Saleh AM, Zaghw AH (2005) Seismic conservation of a slender historical Mamluk-style minaret by passive control techniques. Structural control and health monitoring 12: 157-177.

[7] Ertek E. Structural modeling and earthquake analysis of Ottoman minarets, MSc Thesis. Gebze Institute of Technology, Gebze, Turkey, 2009.

[8] Doğangün A, Acar R, Sezen H, Livaoglu R (2008) Investigation of dynamic response of masonry minaret structures. Bull Earthquake Engineering 6: 505-517.

[9] Pena F, Laurenço PB, Mendes N, Oliveira DV (2010) Numerical models for the seismic assessment of an old masonry tower. Engineering Structures 32: 1466-1478.

[10] Haciefendioglu K, Birinci F (2011) Stochastic dynamic response of masonry minarets subjected to random blast and earthquake-induced ground motions. The Structural Design of Tall and Special Buildings 20: 669-678.

[11] Altunisik AC (2011) Dynamic response of masonry minarets strengthened with fiber reinforced polymer (FRP) composites. Natural Hazards and Earth System Sciences 11: 20112019.

[12] Bayraktar A, Altunışık AC, Sevim B, Türker T, Akköse M, Çoşkun N (2008) Modal analysis, experimental validation and calibration of a historical masonry minaret. Journal of Testing and Evaluation 36(6): 516-524.

[13] Bayraktar A, Altunışık AC, Sevim B, Türker T (2009) Seismic response of a historical masonry minaret using a finite element model updated with operational modal testing. Journal of Vibration and Control 17: 129-149.

[14] Portioli F, Mammana O, Landolfo R, Mazzolani FM, Krstevska L, Tashkov L, Gramatikov K (2011) Seismic retrofitting of Mustafa Pasha Mosque in Skopje. Finite element analysis, Journal of Earthquake Engineering 15: 620-639.

[15] Gang L, Sheliang W, Yingxian Z () Research on seismic reliability of Guang Minaret in Frequently-Occurred Earthquake. Proceedings of the 12th International Conference on Inspection, Appraisal Repairs and Maintenance of Structures, 23-25 April, 2010, Yantai, China.
[16] Oliveira CS, Çaktı E, Stengel D, Branco M (2012) Minaret behavior under earthquake loading: The case of historical Istanbul. Earthquake Engineering and Structural Dynamics 41: 19-39.

[17] Şahin A, Bayraktar A, Özcan DM, Sevim B, Altunışık AC, Türker T (2011) Dynamic field test, system identification and modal validation of an RC minaret: preprocessing and postprocessing the wind-induced ambient vibration data. Journal of Performance of Constructed Facilities 25: 336-356.

[18] Firat YG. A study of the structural response of minarets in the 1999 Anatolian earthquakes, MSc Thesis, Purdue University, West Lafayette (IN), USA, 2001.

[19] Altunisik AC (2013) Comparison of earthquake behavior of reinforced concrete minarets using fiber-reinforced polymer composite. The Structural Design of Tall and Special buildings 22: 749-758.

[20] ANSYS (2006). Swanson Analysis System, US.

[21] Bathe KJ. Finite Element Procedures in Engineering Analysis. Prentice-Hall, Englewood Cliffs, New Jersey, 1996.

[22] Acar R. Investigation of behaviors of monumental tower structures and development of alternative systems. MSc Thesis, Karadeniz Technical University, Turkey, 2009.

[23] Türkeli E, Livaoğlu R, Doğangün A (2015) Dynamic response of traditional and buttressed reinforced concrete minarets. Engineering Failure Analysis 49: 31-48.

[24] [Url-1] http://www.iku.edu.tr/TR/userfiles/2011 vanrapor.pdf, 04.05.2012.

[25] [Url-2] http://mehmetsezer.aatml.net/kocatepe. html, 04.05.2012.

[26] [Url-3] PEER (Pacific Earthquake Engineering Research Center), http://peer.berkeley.edu/smcat /data, 11.06.2012. 